\title{
FORAGE YIELD AND GRAZING EFFICIENCY ON ROTATIONALLY STOCKED PASTURES OF 'Tanzania-1' GUINEAGRASS AND ‘Guaçu’ ELEPHANTGRASS
}

\author{
Carlos Guilherme Silveira Pedreira ${ }^{1 *}$; Frederico Alberto de Andrade Rosseto ${ }^{1}$; Sila Carneiro da \\ Silva $^{1}$; Luiz Gustavo Nussio ${ }^{1}$; Leonardo Simões de Barros Moreno ${ }^{1}$; Maria Lúcia Pereira Lima²; \\ Paulo Roberto Leme ${ }^{3}$ \\ ${ }^{1}$ USP/ESALQ - Depto. de Zootecnia, C.P. 9 -13418-900 - Piracicaba, SP - Brasil. \\ 'APTA Regional Centro Leste, C.P. 271 - 14030-670 - Ribeirão Preto, SP - Brasil. \\ ${ }^{3}$ USP/FZEA - Depto. de Zootecnia, Av. Duque de Caxias Norte, 225 - 13535-900 - Pirassununga, SP - Brasil. \\ *Corresponding author <cgspedre@esalq.usp.br>
}

ABSTRACT: The potential carrying capacity of tropical pastures depends not only on the productivity of the forage species and the amount of forage on offer, but also on the efficiency with which the produced herbage is harvested by the grazing animal. This study was conducted to assess the yield and grazing efficiency on 'Guaçu' elephantgrass (Pennisetum purpureum Schum.) and 'Tanzania-1' guineagrass (Panicum maximum Jacq.) pastures under rotational stocking. Forage accumulation, daily accumulation rates, grazing losses, bulk density, and utilization efficiency were measured. Treatments (forages) were replicated four times in a completely randomized design. Total forage dry matter (DM) yield over 214 days of grazing were 23850 and $15000 \mathrm{~kg} \mathrm{ha}^{-1}$, for the elephantgrass and the guineagrass, respectively, using $250 \mathrm{~kg} \mathrm{~N} \mathrm{ha}^{-1}$ in split applications after each grazing. Mean forage accumulation per grazing cycle was 7950 and $5010 \mathrm{~kg} \mathrm{ha}^{-1}$ and mean daily accumulation rates were 137 and $86 \mathrm{~kg}^{-1} \mathrm{ha}^{-1} \mathrm{~d}^{-1}$ for $P$. purpureum and $P$. maximum, respectively. Grazing losses per cycle averaged 1040 and $880 \mathrm{~kg} \mathrm{ha}^{-1}$, for grazing efficiencies of 52 and $37 \%$ for the Pennisetum and the Panicum, respectively. Mean seasonal stocking rate was $5.1 \mathrm{AU}$ (animal unit $=500 \mathrm{~kg} \mathrm{LW}$ ) per ha on P. purpureum and $3 \mathrm{AU}^{-1} \mathrm{ha}^{-1}$ on $P$. maximum pastures. For both species, productivity potential resides on the high pasture carrying capacity, particularly when there are no soil fertility limitations during the warm/rainy season. Based on growth potential and stem elongation characteristics, 'Guaçu' requires better management skills and 'Tanzania-1' has a more pronounced seasonal growth, as expressed by seasonal yields, apparently due to their contrasting responses to temperature and daylength.

Key words: losses due to grazing, forage accumulation, accumulation rates, forage allowance

\section{PRODUÇÃO DE FORRAGEM E EFICIÊNCIA DE PASTEJO EM PASTAGENS DE CAPIM TANZÂNIA-1 E DE CAPIM-GUAÇU SOB LOTAÇÃO ROTACIONADA}

RESUMO: A capacidade de suporte potencial das pastagens tropicais depende não apenas da produtividade e da quantidade de forragem em oferta, mas também da eficiência com a qual a forragem produzida é colhida pelo animal em pastejo. O presente estudo foi conduzido com o objetivo de quantificar a produtividade e a eficiência de pastejo em pastagens de capim-Guaçu (Pennisetum purpureum Schum.) e de capim Tanzânia-1 (Panicum maximum Jacq.) sob lotação rotacionada. Acúmulo de forragem, taxas médias diárias de acúmulo, perdas por pastejo, densidade volumétrica da forragem e a eficiência de pastejo foram medidas. O delineamento foi completamente casualizado com dois tratamentos e quatro repetições. A produção total de matéria seca (MS) durante 214 dias de pastejo foi 23850 e $15000 \mathrm{~kg} \mathrm{ha}^{-1}$ para os capins Guaçu e Tanzânia-1, respectivamente, com $250 \mathrm{~kg} \mathrm{~N} \mathrm{ha}^{-1}$ aplicados parceladamente após cada pastejo. $\mathrm{O}$ acúmulo médio de forragem por ciclo de pastejo foi 7950 e $5010 \mathrm{~kg} \mathrm{MS} \mathrm{ha}^{-1}$ e a taxa média diária de acúmulo foi 137 e $86 \mathrm{~kg} \mathrm{MS} \mathrm{ha}^{-1}$ dia $^{-1}$ para o Guaçu e para o Tanzânia, respectivamente. As perdas de forragem médias por ciclo de pastejo foram 1040 e $880 \mathrm{~kg} \mathrm{MS} \mathrm{ha}^{-1}$, resultando em eficiências de pastejo de 52 e $37 \%$ para o P. purpureum e para o P. maximum, respectivamente. A taxa de lotação média da estação de pastejo foi 5,1 UA (unidade animal $=500 \mathrm{~kg}$ PV) no Guaçu e 3 UA ha $^{-1}$ no Tanzânia-1. Em ambas as espécies o potencial produtivo reside na alta capacidade de suporte, particularmente quando não houver limitações de fertilidade do solo durante o verão. O Guaçu, devido às características de potencial produtivo e de alongamento de hastes, requer maior habilidade por parte do manejador, enquanto que o Tanzânia-1 apresenta produção mais estacional, conforme indicado pelas produções de cada estação, o que aparentemente está relacionado com as respostas à temperatura e ao fotoperíodo, contrastantes entre as duas espécies.

Palavras-chave: perdas por pastejo, acúmulo de forragem, taxa de acúmulo, oferta de forragem

Sci. Agric. (Piracicaba, Braz.), v.62, n.5, p.433-439, Sept./Oct. 2005 


\section{INTRODUCTION}

In pasture ecosystems, produced forage can be (i) consumed by the grazing animal, (ii) left for stubble, needed for regrowth, or (iii) lost mechanically due to grazing and incorporated to dead material or ground litter after senescence and decomposition (Hodgson, 1990). At any given level of net forage accumulation, and considering the need to support satisfactory intake and animal performance levels, a range of combinations between stocking rate and performance can result in similar animal productivities and this will ultimately define the economic viability of the system, since increased carrying capacity is associated with increased productivity of milk and meat.

Two major sward structure components, height and bulk density, affect the ease with which the forage can be harvested by the grazing animal and, in practice, relate to the concepts of forage mass (FM) and forage allowance. High sward bulk densities facilitate forage prehension by grazing animals, justifying the need for establishing target sward characteristics, together with forage mass and allowance, that make intake and performance goals achievable (Silva \& Pedreira, 1996).

In grazed pastures combinations between pre- and post-graze FM within a level of forage allowance and across forage species, make for a variety of levels of forage utilization (Blaser et al., 1986). As allowance decreases, also do intake and animal performance, although the level of utilization of accumulated herbage increases. This relationship is highly affected by sward structure. If post-graze residue (stubble height or residual mass of green leaves) is too low, regrowth vigor may be hindered, whereas excessively high post-graze FM is associated with tissue losses to senescence and death (Hodgson, 1990) and low harvest efficiency.

The high forage accumulation potential of $\mathrm{C}_{4}$ grasses such as $P$. purpureum and $P$. maximum is recognized as key to the success of forage-based animal production systems in the tropics. Materialization of such success, however, requires that produced forage be efficiently utilized (harvested) by the grazing animal with minimal loss and adequate stubble left for vigorous regrowth, both of which are highly species- and cultivarspecific. The objective of this research was to assess, for two major, high yielding tropical forage grasses intensively managed, the magnitude of the levels of utilization efficiency as related to herbage produced and as affected by some of their agronomic characteristics. Specific objectives were to (i) measure total forage accumulation and accumulation rates during the summer rainy season and into the dry season, (ii) characterize sward structure, measured as whole sward bulk density, under "recommended" management practices, and (iii) quantify the efficiency of utilization of the forage accumulated, by measuring disappearance and loss due to grazing.

\section{MATERIAL AND METHODS}

The research was conducted in Ribeirão Preto,

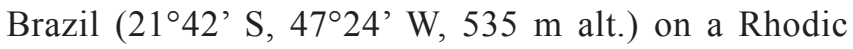
Ferralsol (FAO, 1989). Pastures of Guaçu elephantgrass and Tanzania-1 guineagrass were grazed under a rotational stocking method for 214 days during the summer rainy season into the early dry season (December 1998 through July 1999; Figure 1). Grazing management imposed was assumed to be "optimal" for each forage, within the level of intensification adopted, and considering the species contrasting morphophysiological and phenological traits (Hanna et al., 2004; Muir \& Jank, 2004). Both species are erect, high-yielding, high-quality, tufted perennials. Tanzania-1 is a sexual $P$. maximum, released by Embrapa Beef Cattle in Brazil, in 1990 (Jank et al., 1997) that grows to $1.2 \mathrm{~m}$, produces up to $130 \mathrm{~kg}$ seed $\mathrm{ha}^{-1}$ and is easy to manage under grazing. It shows a pronounced seasonal growth (only $10 \%$ of the total annual yield during the 6 months of the dry season) with plants flowering profusely in early- to mid-autumn (beginning of dry season), with intense stem elongation and severe decline in vegetative growth, which often dries out. Guaçu is a vegetatively-propagated elephantgrass belonging to the Cameroon group, characterized by tall, erect plants (up to $5 \mathrm{~m}$ in free growth) with thick stems, and late-season or no flowering (Pereira, 1994; Hanna et al., 2004).

The elephantgrass "system" was a 7.88-ha pasture divided into twenty-one 0.375 -ha paddocks, each of which was grazed for two days followed by a 40-day rest period. Before grazing was initiated (October), paddocks were mowed to about $45 \mathrm{~cm}$ for staging and uniformization. During the experimental period, started on 7 Dec., 1998, stocking rates were often adjusted, so that a $45-\mathrm{cm}$ stubble was left after grazing. For Tanzania-1, a 12.1-ha pasture was divided into eleven 1.1-ha paddocks grazed in a 35-d cycle (3 days of grazing followed by 32 days of rest). The two extra days needed to complete the rest period were spent on a Tanzania-1 pas-

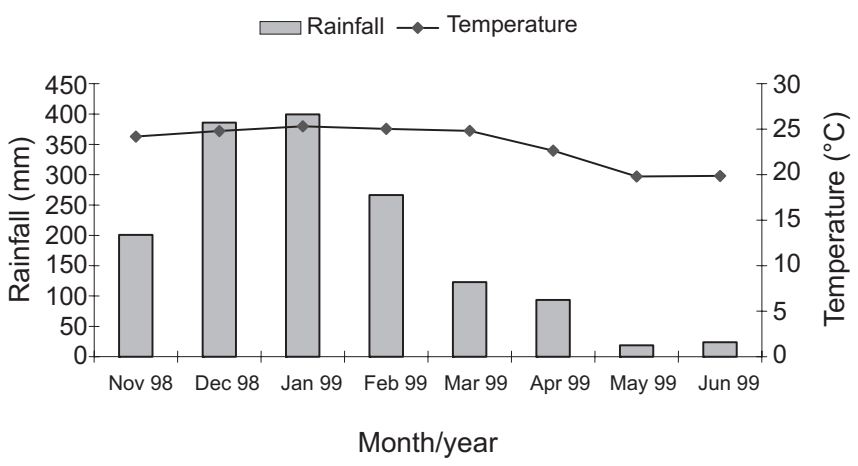

Figure 1 - Monthly rainfall and mean temperature from November 1998 to June 1999 in Ribeirão Preto, SP, Brazil. 
ture outside the experiment. Grazing on the Tanzania-1 pastures commenced on 12 Nov., 1998, and the stocking rates were also adjusted regularly to achieve a target postgraze stubble, in this case $35 \mathrm{~cm}$ on average.

Soil fertility was managed under a semi-intensive level to allow for the expression of the forages' genetic potential. According to soil analyses (samples taken in June, 1998), $18.6 \mathrm{Mg}$ of a highly reactive dolomitic lime, $2 \mathrm{Mg}$ of simple superphosphate, and $8 \mathrm{Mg}$ potassium chloride were applied differentially (on a per-paddock basis, over the entire experimental site) in October and November 1998, so that soil fertility became not limiting for the expression of forage production potential of both species. A second soil analysis from samples taken in March 1999 (Table 1) indicated that correction procedures had been successful. "Production" fertilization during the experimental period consisted of split-applications totalizing $250 \mathrm{~kg} \mathrm{~N} \mathrm{ha}^{-1}$ as ammonium sulphate, based on projections of forage production and nutrient extraction by the total accumulated phytomass. The total rate was split in four (Guaçu) or five (Tanzania-1) topdress applications immediately after grazing in each paddock.

Pastures were grazed by lactating crossbred [Gir (Bos indicus L.) $\times$ Holstein (Bos taurus $\mathrm{L}$.)] cows weighing $477 \pm 17.9 \mathrm{~kg}$ on average, producing a mean $11 \mathrm{~kg}$ milk $\mathrm{d}^{-1}$. Animals were divided into three categories according to performance, and concentrate $\left(180 \mathrm{~g} \mathrm{~kg}^{-1}\right.$ crude protein and $\left.720 \mathrm{~g} \mathrm{~kg}^{-1} \mathrm{TDN}\right)$ supplementation was assigned to animals within three groups: $4 \mathrm{~kg}$ concentrate per cow for cows producing $>15 \mathrm{~kg}$ milk d ${ }^{-1} ; 2 \mathrm{~kg}$ for cows producing between 9 and $15 \mathrm{~kg} \mathrm{~d}^{-1}$; and no supplementation for cows producing $<9 \mathrm{~kg} \mathrm{~d}^{-1}$.

The trial was set up in a completely randomized experimental design with two treatments and four replications. Within grass, each replication was one of four consecutive paddocks - "sampling paddocks" - in the grazing sequence, and these paddocks were assumed to be representative of their respective systems. Grazing events in the two grass systems were such that they matched in time, to the extent that the different cycles allowed. Stocking rates on the sampling paddocks were adjusted as often as twice a day so that the target post-graze stubble height was achieved at the end of the grazing period. Response variables were measured on each sampling paddock of each grass system, in each grazing cycle.
Forage mass was measured immediately before (pre-) and immediately after (post-) grazing in the sampling paddocks. For that purpose, three sites where FM was considered to be representative of the paddock's mean FM, through visual appraisal, were selected and the forage inside a $2 \times 2 \mathrm{~m}$ quadrat was clipped at $20 \mathrm{~cm}$. The forage was weighed fresh in the field, and a subsample ( $\sim 1 \mathrm{~kg}$, also weighed fresh in the field), was taken to a forced-air oven and dried at $65^{\circ} \mathrm{C}$ to constant weight. Dry matter concentrations in the fresh forage were used to calculate pre- and post-graze FM. Before the pasture was sampled, pre-graze mean sward height was measured within the quadrats, by taking ruler measurements of the tussocks inside the quadrat. The height of each tussock was considered from soil level to the curvature of the youngest fully expanded leaf as it stood in the field. Sward bulk density was calculated by dividing pre-graze FM by sward height, subtracting the $20 \mathrm{~cm}$ that corresponded to the sampling height. Forage accumulation was calculated for each rest period by subtracting post-graze FM of the $(n-1)^{\text {th }}$ cycle from pre-graze FM of the $n^{\text {th }}$ cycle. Mean daily accumulation rate was calculated by dividing forage accumulation by the number of days of rest. FM below the sampling height was measured in January and April by clipping the forage from 0 to $20 \mathrm{~cm}$ in the $4-\mathrm{m}^{2}$ quadrats after the pre-graze FM samples were cut.

Forage losses were quantified after each grazing. In each sampling paddock, two $6-\mathrm{m}^{2}$ areas were selected at random, each identified by four wooden stakes firmly hammered to the soil. The soil surface within these sites was cleaned of all plant material and litter immediately before the paddock was open to the animals. Lost (wasted) forage was considered to be all plant material that was mechanically damaged (even if still attached to the tillers, assuming it would be dead before the next grazing event), trampled or fouled upon, plus all forage material on the soil surface. This material was collected, dried in a forced-air oven at $65^{\circ} \mathrm{C}$ to constant weight, and weighed. As much as possible, the same sites were used for this purpose during the entire experiment, but were replaced when necessary. Forage losses were calculated as a proportion of both total pre-graze FM and accumulated forage in the previous regrowth. Grazing efficiency was calculated as the ratio between the amount of forage that disappeared due to animal intake (assumed to be the

Table 1 - Chemical characteristics of the soil under Guaçu elephantgrass and Tanzania-1 guineagrass pastures after application of correctives.

\begin{tabular}{|c|c|c|c|c|c|c|c|c|}
\hline Grass & $\begin{array}{c}\mathrm{pH} \mathrm{CaCl} \\
\left(0.01 \mathrm{~mol} \mathrm{~L}^{-1}\right)\end{array}$ & $\mathrm{OM}$ & $\mathrm{P}$ (resin) & K & $\mathrm{Ca}$ & $\mathrm{Mg}$ & CEC & $\mathrm{V}$ \\
\hline & & $\mathrm{g} \mathrm{dm}^{-3}$ & $\mathrm{mg} \mathrm{dm}^{-3}$ & - & mmolc $\mathrm{dm}^{-3}$ & $\ldots$ & $\ldots$ & $\%$ \\
\hline Guaçu & 4.9 & 41 & 29 & 3.3 & 74 & 31 & 155 & 70 \\
\hline Tanzania-1 & 4.9 & 38 & 28 & 5.2 & 71 & 35 & 160 & 71 \\
\hline
\end{tabular}

$\mathrm{OM}=$ organic matter; $\mathrm{CEC}=$ cation exchange capacity; $\mathrm{V}=$ base saturation; mmolc $=$ millimols, charge-equivalent 
difference between pre-graze FM and post-graze FM plus losses) and pre-graze FM, within the same grazing cycle, or forage accumulated during the previous rest period.

Because of contrasting differences between grasses as to their responses to environmental factors, mainly temperature and daylength, an over-time appreciation of the responses studied was considered pertinent, as it might impact management decisions by the producer in areas with similar climatic characteristics. Thus, data are presented for the entire length of the experiment but also for three "seasons" within the experimental period: (1) mid-rainy season (from 12 Dec., 1998 to 16 Feb., 1999), (2) late-rainy season (from $17 \mathrm{Feb}$. to 15 Apr., 1999), and (3) early-dry season (from 16 Apr. to 12 Jun., 1999). Due to differences in grazing cycle length between grasses, a cycle may have been divided into two portions, which were weighed for their contributions to seasons, if a cycle began in one season and ended in another.

Data were analyzed using the GLM procedure of SAS (SAS Institute, Inc., 1989) after testing for homogeneity of variances. "Season" was considered a subplot in a split-plot arrangement, using the REPEATED statement. Means were compared using the LSMEANS at the $10 \%$ significance level.

\section{RESULTS AND DISCUSSION}

Total forage accumulation over 214 days differed $(P=0.0001)$ between species, averaging 23.9 and $15 \mathrm{Mg}$ $\mathrm{DM} \mathrm{ha}^{-1}$ for $P$. purpureum and $P$. maximum, respectively. There was pronounced decline $(P=0.0001)$ in forage yield on Tanzania-1 pastures whereas Guaçu sustained $(P=0.6698)$ a mean $8.8 \mathrm{Mg} \mathrm{ha}^{-1}$ throughout the rainy season (mid- and late-), but dropping $(P=0.0274)$ to $6.2 \mathrm{Mg}$ $\mathrm{ha}^{-1}$ for the eight weeks of the early-dry season (Table 2). The high yield potential of Pennisetum and Panicum forages has long been known and reported. Examples include the work of Sotomayor-Rios et al. (1971), who recorded total annual forage yields of $45 \mathrm{Mg} \mathrm{DM} \mathrm{ha}{ }^{-1}$ for $P$. maximum, and that of Vicente-Chandler et al. (1959), who measured a $83 \mathrm{Mg} \mathrm{ha}^{-1}$ total annual forage accumulation for $P$. purpureum. Seasonal yields typically decline markedly to-

Table 2 - Mean forage accumulation of Guaçu elephantgrass and Tanzania-1 grass pastures in three seasons within the experimental period.

\begin{tabular}{lccc}
\hline \multirow{2}{*}{ Grass } & \multicolumn{3}{c}{ Season } \\
\cline { 2 - 4 } & Mid-rainy & Late-rainy & Early-dry \\
\hline Guaçu & 8650 & 8990 & 6210 \\
Tanzania-1 & 7050 & 5730 & 2250 \\
SE & 239 & 566 & 441 \\
\hline
\end{tabular}

$\mathrm{SE}=$ standard error; Season SE within grasses $=376 \mathrm{~kg} \mathrm{DM} \mathrm{ha}^{-1}$ ward the dry season, even where irrigation is supplied, suggesting that environmental restraints other that moisture also drive yield responses (Müller et al., 2002).

Mid-rainy season yields were similar $(P=$ 0.1702 ), averaging $7.8 \mathrm{Mg} \mathrm{ha}^{-1}$ between species, but Guaçu accumulated $3.3 \mathrm{Mg} \mathrm{ha}^{-1}$ more $(P=0.0152)$ than Tanzania-1 in the late-rainy season. This difference became greater $\left(4 \mathrm{Mg} \mathrm{ha}^{-1}\right.$ in favor of Guaçu; $\left.P=0.0001\right)$ in the early-dry season. Daily forage accumulation rates followed the same trend, averaging 149, 155, and $107 \mathrm{~kg}$ DM ha ${ }^{-1} \mathrm{~d}^{-1}$ for Guaçu and 121, 99, and $39 \mathrm{~kg} \mathrm{ha}^{-1} \mathrm{~d}^{-1}$ for Tanzania-1, in the mid-rainy, late-rainy, and early-dry seasons, respectively. Mean daily forage accumulation rates measured in this study for Guaçu elephantgrass (136 kg DM ha ${ }^{-1} \mathrm{~d}^{-1}$ ) are higher than those reported by Balsalobre (1996), of $94 \mathrm{~kg} \mathrm{ha}^{-1} \mathrm{~d}^{-1}$ for $P$. purpureum cv. Napier at a nearby location during the rainy season, with similar $\mathrm{N}$ input. As for the Tanzania-1 pastures $\left(88 \mathrm{~kg} \mathrm{ha}^{-1} \mathrm{~d}^{-1}\right)$, Santos et al. (1999) measured $113 \mathrm{~kg} \mathrm{ha}^{-1} \mathrm{~d}^{-1}$, under similar management, same season and nearby location. If early-rainy season forage accumulation (not measured) of Guaçu pastures is assumed to be equivalent to that of laterainy season, total rainy-season accumulation would approach $27 \mathrm{Mg} \mathrm{DM} \mathrm{ha}{ }^{-1}$. In addition, if mean post-graze FM $\left(2.7 \mathrm{Mg} \mathrm{ha}^{-1}\right)$ and the mean FM below the 20-cm sampling height $\left(3.4 \mathrm{Mg} \mathrm{ha}^{-1}\right)$ are added to that value, a total forage accumulation of $32.6 \mathrm{Mg} \mathrm{DM} \mathrm{ha}{ }^{-1}$ is found for the summer rainy season (early October to mid April for that location). Similar assumptions result in a $6.2 \mathrm{Mg} \mathrm{DM}^{-}{ }^{-}$ ${ }^{1} \mathrm{DM}$ accumulation for the cool dry season (May to September), resulting in an approximate total annual yield for Guaçu, of $39 \mathrm{Mg} \mathrm{DM} \mathrm{ha}^{-1}$. Using the same assumptions and computational procedures for Tanzania-1 would result in a $24.9 \mathrm{Mg} D M ~ h a^{-1}$ rainy season forage accumulation, for an annual total of $27 \mathrm{Mg} \mathrm{ha}^{-1}$, with negligible accumulation during most of the cool dry season. Although speculative to some extent, this exercise indicates that the yield potential of Tanzania- 1 is about $70 \%$ that of Guaçu, on high-fertility soils, under adequate management.

The proportion of total forage that was lost (wasted) due to grazing was affected by forage species $(P=0.016)$, season $(P=0.0112)$ and the species $\times$ season interaction $(P=0.0692)$. In the mid-rainy season (Figure 2), about $20 \%$ of the forage (in relation to pregraze FM) was lost for both species $(P=0.4727)$. Laterainy season losses were also similar $(P=0.4596)$ between species, averaging approximately $15 \%$, but much higher $(P=0.0005)$ in the early-dry season for Tanzania-1 $(16.5 \%)$ than for Guaçu (6.4\%). In this context, the use of forage allowance as guideline for adjustment of stocking rates requires that $\mathrm{FM}$ be measured or estimated regularly. In addition, if sward conditions are such as to favor the accumulation of significant amounts of

Sci. Agric. (Piracicaba, Braz.), v.62, n.5, p.433-439, Sept./Oct. 2005 


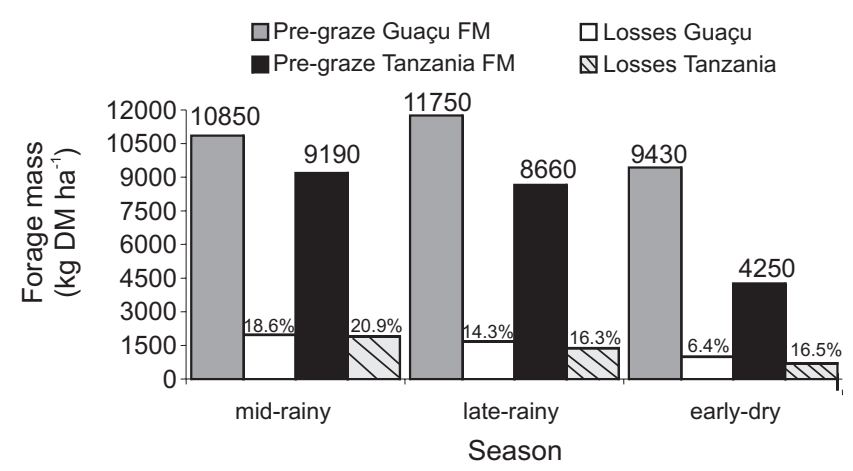

Figure 2 - Mean pre-graze forage mass (FM) and grazing losses on Guaçu elephantgrass and Tanzania-1 guineagrass pastures in three seasons during the experimental period. Percent values above bars refer to losses as a proportion of pregraze FM.

senescing/dead material, it is often more relevant to express FM as green DM instead of total DM (Prache, 1997; Roguet et al., 1998). Keeping forage allowance constant throughout the grazing season to achieve performance goals regularly may be difficult. This happens because forage accumulation rates plus plant part composition and proportion of dead material in pastures of $\mathrm{C}_{4}$ grasses (many of which undergo continuous stem elongation, even while vegetative) are highly variable in tropical environments, especially under intensive management. According to Hillesheim \& Corsi (1990), the efficiency with which forage is harvested by the grazing animal is usually in the range of 30 to $80 \%$, depending on management. The same authors measured a $38 \%$ efficiency of utilization on pastures of elephantgrass cv. Napier managed at lax (i.e., not restrictive to intake) allowance levels. Balsalobre (1996), also working with Napier, reported $32 \%$ efficiency of utilization under the same forage allowance.

If grazing losses are expressed in relation to the accumulated forage, a species effect $(P=0.0947)$ is detected but not a season $(P=0.6383)$ or a species $\times$ season interaction $(P=0.3629)$ effects. In the mid-rainy season grazing losses in relation to accumulated forage were similar $(P=0.6480)$ between species, an average of $29.3 \%$ (Figure 3 ). In the late-rainy season, losses were still similar (mean $26.6 \% ; P=0.2143$ ) between species but much greater $(P=0.0003)$ on Tanzania-1 $(34.8 \%)$ than on Guaçu (10.2\%) pastures in the early-dry season. Overall, the efficiency with which Guaçu elephantgrass forage was harvested by the grazing animals, as a proportion of total pre-graze FM, varied little averaging 51\%, whereas on the Tanzania-1 pastures it fell from 44.5 to $31.3 \%$, from mid/late-rainy to early-dry seasons.

There were no indications that forage mass was restrictive to intake at any point. Mean forage allowances were 9.2 and $16.7 \mathrm{~kg} \mathrm{DM} \mathrm{kg} \mathrm{LW}^{-1} \mathrm{~d}^{-1}$ for Guaçu and Tanzania-1, respectively. Higher allowance levels on Tanzania-1 were due to the greater need to reduce stocking rates on these pastures with the onset of the dry season, com-

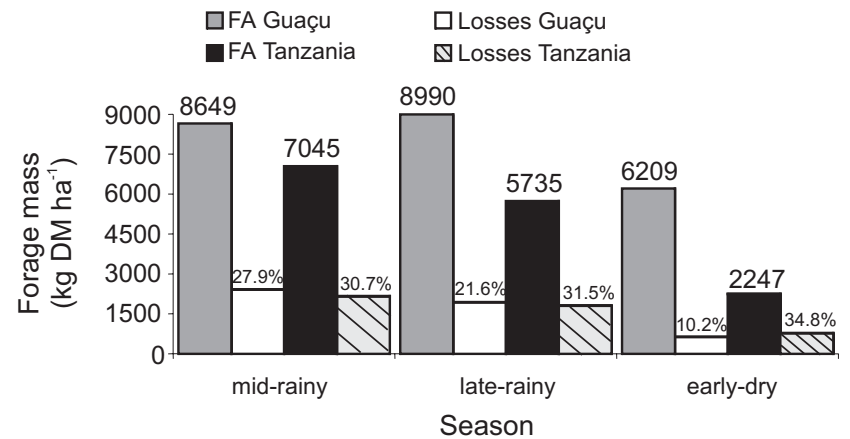

Figure 3 - Forage accumulation (FA) and grazing losses on Guaçu elephantgrass and Tanzania-1 guineagrass pastures in three seasons during the experimental period. Percent values above bars refer to losses as a proportion of FA.

pared with the Guaçu pastures which sustained higher stocking rates. Hillesheim \& Corsi (1990), Balsalobre (1996), and Teixeira et al. (1999) reported decreased grazing efficiencies, increased stubble heights and post-graze FM on $P$. purpureum and $P$. maximum pastures as the grazing season progressed and allowance was kept constant. For these pastures, management on high fertility soils may benefit from decreasing forage allowance and increasing grazing efficiency so as to avoid excessive losses of forage to senescence and death. However, this may not be the best option in systems where varying stocking rates is unpractical, since a fixed rest period results in large variations in forage accumulation per grazing cycle, requiring the length of the grazing cycle to be adjusted accordingly.

Research with $P$. maximum cv. Mombaça (Carnevalli, 2003) under rotational stocking, grazed at either 95 or $100 \%$ canopy light interception (LI) indicated that initiation of grazing at $95 \%$ LI is better for the maintenance of adequate sward structure (ease with which a target stubble height is reached), for maximization of grazing efficiency, and for forage productivity and nutritive value. This condition (95\% LI) appears to be consistently associated with a $90-\mathrm{cm}$ sward height, regardless of phenological stage, whereas a $100 \%$ pregraze LI resulted in similar total forage accumulation (mean of $22.5 \mathrm{Mg} \mathrm{ha}^{-1}$ ) over a 411-d grazing season, but with higher proportions of stem (15 vs. $8 \%$ of total pregraze FM) and dead material (10 vs. $6.5 \%$ of FM), lower forage concentrations of crude protein (90 vs. $112 \mathrm{~g} \mathrm{~kg}^{-1}$ ) and digestible organic matter (550 vs. $\left.581 \mathrm{~g} \mathrm{~kg}^{-1}\right)$ in pregraze forage. Under these circumstances, rest periods were variable ( 22 to $35 \mathrm{~d}$ and 95 to $186 \mathrm{~d}$ during the rainy and dry seasons, respectively) but on pastures grazed at $100 \%$ pre-graze LI, the post-graze stubble could not be kept at the target height, increasing from 30 to $51 \mathrm{~cm}$.

In the present study, post-graze FM increased as the season progressed, although stubble heights were kept 
relatively constant at 54 and $43 \mathrm{~cm}$ for Guaçu and Tanzania-1, respectively. This required good, labor-intensive management and the adjustment of stocking rates according to forage accumulation, besides the need to respect target stubble heights, all of which made forage allowance a response- rather than a treatment-variable. Therefore, management decisions should involve the accurate assessment of the compromise between sward state, animal performance and productivity, plus the impact of each alternative on pasture productivity and persistence together with forage nutritive value, both within and across grazing seasons.

Besides its role as a sward structure component (as it impacts leaf area index, light interception, regrowth potential, and stand persistence) post-graze stubble height represents an important resource for individual plants. Reserves such as non-structural carbohydrates and nitrogenous compounds are often stored in stem bases, requiring that a minimal, critical stubble be left to ensure stand productivity and longevity (Hillesheim \& Corsi, 1990). Thus, the argument can be made in favor of excluding the stubble mass (which can be as much as $40-50 \%$ of the total in $P$. purpureum) when computing grazing efficiency and using "accumulated forage" (i.e., that above the stubble) as the denominator. For the present study, this procedure would result in efficiencies of utilization between 73 and $91 \%$ for the elephantgrass, and 68 to $74 \%$ for the guineagrass. Regardless of calculation method chosen, however, these efficiencies are associated with the decline in forage accumulation and accumulation rates from the beginning to the end of the experimental period. Starting in Apr/May, Tanzania-1 plants turned reproductive, with most leaf tissue drying out and dying as panicles emerged, whereas Guaçu stayed vegetative with high proportions of green leaf material still on offer.

Mean sward bulk density was lower $(P=0.0464)$ on Guaçu $\left(71 \mathrm{~kg} \mathrm{DM} \mathrm{ha}^{-1} \mathrm{~cm}^{-1}\right)$ than on Tanzania-1 (95 $\mathrm{kg} \mathrm{DM} \mathrm{ha} \mathrm{cm}^{-1}$ ) pastures (Table 3) suggesting that intake would be favored for animals grazing on Tanzania1 pastures, due to increased bite weight. Animals grazing on Guaçu pastures might have to graze for longer periods of time to make up for the lower bite weight. Bulk

Table 3 - Mean pre-graze sward bulk density of Guaçu elephantgrass and Tanzania-1 grass in three seasons within the experimental period.

\begin{tabular}{lccc}
\hline & \multicolumn{3}{c}{ Season } \\
\cline { 2 - 4 } Grass & Mid-rainy & Late-rainy & Early-dry \\
\hline \multirow{2}{*}{ Guaçu } & 63.4 & 60.3 & 88.6 \\
Tanzania-1 & 85.7 & 85 & 114.5 \\
SE & 2.3 & 3.4 & 3 \\
\hline
\end{tabular}

$\mathrm{SE}=$ standard error; Season SE within grasses $=2.4 \mathrm{~kg} \mathrm{DM} \mathrm{ha}^{-1} \mathrm{~cm}^{-1}$ density was also affected by season $(P=0.0004)$ but not by the species $\times$ season interaction $(P=0.8517)$. During the rainy season (mid- and late-) the mean sward bulk density of Guaçu pastures was $62 \mathrm{~kg} D M \mathrm{ha}^{-1} \mathrm{~cm}^{-1}$ whereas that of Tanzania-1 was $85 \mathrm{~kg} \mathrm{ha}^{-1} \mathrm{~cm}^{-1}\left(P_{\text {mid-rainy }}\right.$ $\left.=0.0464 ; P_{\text {late-rainy }}=0.0029\right)$. In the early-dry season, both grasses had their sward bulk density increased (Table 3 ), with Tanzania-1 sustaining higher values $(P=0.0249)$.

Grazing efficiency on Tanzania-1 pastures was more variable and likely influenced by stocking rate (4 $\mathrm{AU} \mathrm{ha}^{-1}$ in Dec, Jan, and Feb; $3.4 \mathrm{AU}_{\text {ha }}{ }^{-1}$ in Mar; $1 \mathrm{AU}$ $\mathrm{ha}^{-1}$ in Apr), than on Guaçu pastures, where it was practically constant as stocking rates ranged from 7 (Feb) to 3.1 $\mathrm{AU}_{\mathrm{Ua}}{ }^{-1}$ (Apr-May). This suggests that behavioral, non-nutritional factors, more related to sward structure than to forage nutritive value, might be controlling intake, although this is speculative. Evidence exists, however, that a wide range of combinations between height and bulk density may correspond to the same forage mass (Carvalho, 1997). Consequently, variations in intake (and thus in grazing efficiency and performance) may be poorly associated with variations in forage mass, as the same mass may present itself in a variety of ways (structures) to the grazing animal. For rotationally-stocked elephantgrass pastures, Carvalho (1997) stated that dairy cows may experience intake restrictions both at the beginning (due to spatial dispersion of the forage on offer) and the end of the grazing period (due to the scarcity of green leaf material). Longer grazing times suggest that intake is being limited by the sward's structural characteristics (Chacon \& Stobbs, 1978; Stobbs, 1973) and, according to Hodgson et al. (1994), bulk density is a major component of sward structure of tropical pastures, whereas sward height is more important in temperate pastures.

Yield and yield-related responses (total forage accumulation, mean daily accumulation rate), as well as grazing efficiency (losses) and structural characteristics (bulk density) of the two forages studied were markedly affected by species attributes (plant morphology, sward structure, phenology) and environment (climatic variations and plant responses to them). The dynamics of the combination temperature/daylength/rainfall results in contrasting performances between the two grasses, especially on phenology. Grazing losses are generally higher when the amount of forage on offer, sward height and stem proportion are higher, suggesting that efficiency and accumulation are inversely related over the grazing season. On the Guaçu pastures, plant morphology and tillering patterns (aerial tillering with less vegetative stem elongation per tiller), plus the absence of flowering, partially explain the better efficiency of utilization. Further study is needed to assess the intake potential of these two forage species under grazing, as well as to compare animal productive responses in intensive systems under a range of soil and climatic conditions in the tropics. 


\section{ACKNOWLEDGEMENTS}

The authors thank CAPES (Coordenação de Aperfeiçoamento de Pessoal de Nível Superior, Brazil) and FAPESP (Fundação de Amparo à Pesquisa do Estado de São Paulo, Brazil) for partial funding of this research. Dr. G. Bufarah, of Instituto de Zootecnia, in Nova Odessa, and Dr. J.R. Nogueira at APTA Regional Centro Leste, in Ribeirão Preto, Brazil are recognized for their administrative and logistical support. L.K. Molan, and M.F.A. Oliveira provided excellent technical assistance during data collection and overall management of experimental pastures.

\section{REFERENCES}

BALSALOBRE, M.A.A. Desempenho de vacas em lactação sob pastejo rotacionado de capim elefante (Pennisetum purpureum Schum.). Piracicaba:USP/ESALQ, 1996. (Dissertação - Mestrado).

BLASER, R.E.; HAMMES, R.C.; FONTENOT, J.P.; BRYANT, H.T.; POLAN, C.E.; WOLF, D.D.; McCLAUGHERTY, F.S.; KLINE, R.G.; MOORE, J.S. Forage-animal management systems. Blacksburg: Virginia Agricultural Experiment Station, 1986. (Bulletin 86-87).

CARNEVALLI, R.A. Dinâmica da rebrotação de pastos de capim Mombaça submetidos a regimes de desfolhação intermitente. Piracicaba:USP/ ESALQ, 2003. (Tese - Doutorado). (http://www.teses.usp.br/teses/ disponiveis/11/11139/tde-09022004-145840/publico/roberta.pdf).

CARVALHO, P.C.F. A estrutura da pastagem e o comportamento ingestivo de ruminantes em pastejo. In: SIMPÓSIO SOBRE AVALIAÇÃO DE PASTAGENS COM ANIMAIS, Maringá, 1997. Anais. Maringá, 1997. p.25-52.

CHACON, E.A.; STOBBS, T.H. Influence of progressive defoliation of a grass sward on the eating behaviour of cattle. Australian Journal of Agricultural Research, v.29, p.89-102, 1978.

FAO. FAO/Unesco soil map of the world, Revised Legend. Wageningen: ISRIC, 1989. (Technical Paper 20).

HANNA, W.W.; CHAPARRO, C.J.; MATHEWS, B.W.; BURNS, J.C.; SOLLENBERGER, L.E.; CARPENTER, J.R. Perennial Pennisetums. In: MOSER, L.E.; BURSON, B.L.; SOLLENBERGER, L.E. (Ed.) Warm-Season $\left(\mathbf{C}_{4}\right)$ Grasses. Madison: ASA/CSSA/SSSA, 2004. p.503535.

HILLESHEIM, A.; CORSI, M. Capim elefante sob pastejo. II. Fatores que afetam as perdas e utilização de matéria seca. Pesquisa Agropecuária Brasileira, v.25, p.1233-1246, 1990.

HODGSON, J. Grazing management - Science into practice. Essex: Longman Scientific \& Techinical, 1990.

HODGSON, J.; CLARK, D.A.; MITCHELL, R.J. Foraging behavior in grazing animals and its impact on plant communities. In: FAHEY, G.C. (ed.). Forage quality, evaluation and utilization. Madison: ASA/CSSA/ SSSA, 1994. p.796-827.
JANK, L.; CALIXTO, S.; COSTA, J.C.G.; SAVIDAN, Y.H.; CURVO, J.B.E. Catalogue of the characterization and evaluation of the Panicum maximum germplasm: Morphological description and agronomical performance. Campo Grande: EMBRAPA-CNPGC. Doc.68. 1997. p.153.

MUIR, J.P.; JANK, L. Guineagrass. In: Moser, L.E.; Burson, B.L.; Sollenberger, L.E. (eds.) Warm-Season $\left(\mathbf{C}_{4}\right)$ Grasses. p.589-621. Madison: ASA/CSSA/SSSA, 2004.

MÜLLER, M.S.; FANCELLI, A.L.; DOURADO-NETO, D.; GARCIA, A.G.; OVEJERO, R.F.L. Produtividade do Panicum maximum cv. Mombaça irrigado, sob pastejo rotacionado. Scientia Agricola, v.59, p.427-433, 2002.

PEREIRA, A.V. Escolha de variedades de capim-elefante. In: PEIXOTO, A.M.; DE MOURA, J.C.; DE FARIA, V.P. (Ed.) Manejo do capim elefante. SIMPÓSIO SOBRE MANEJO DA PASTAGEM, Piracicaba: FEALQ, 1994. p.47-62.

PRACHE, S. Intake rate, intake per bite and time per bite of lactating ewes on vegetative and reproductive swards. Applied Animal Behaviour Science, v.52, p.53-64, 1997.

ROGUET, C.; PRACHE, S.; PETIT, M. Feeding station behaviour of ewes in response to forage availability and sward phenological stage. Applied Animal Behaviour Science, v.56, p.187-201, 1998.

SANTOS, P.M.; CORSI, M.; BALSALOBRE, M.A.A. Efeito da frequência de pastejo e da época do ano sobre a produção e qualidade em Panicum maximum cvs. Tanzânia e Mombaça. Revista Brasileira de Zootecnia, v.28, p.244-249, 1999

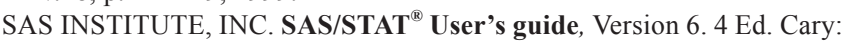
SAS Institute, 1989. v.2.

SILVA, S.C.; PEDREIRA, C.G.S. Fatores condicionantes e predisponentes da produção animal a pasto. In: PEIXOTO, A.M.; DE MOURA, J.C.; DE FARIA, V.P. (Ed.) Produção de bovinos a pasto. Piracicaba: FEALQ, 1996. p.97-122.

SOTOMAYOR-RIOS A.; ACOSTA-MATIEZA, A.; VELEZ-FORTUNO, J. Yield comparison and plant character correlations of 16 Panicum acessions. Journal of Agriculture of the University of Puerto Rico, v.55, p.174-183, 1971.

STOBBS, T.H. The effects of plant structure on the intake of tropical pastures. I. Variation in the bite size of grazing cattle. Australian Journal of Agricultural Research, v.24, p.809-819, 1973.

TEIXEIRA, E.I.; MATTOS, W.R.S.; CAMARGO, A.C.; ROSSETO, F.A.A.; TEIXEIRA, C.S.P. Avaliação de produção e utilização de uma pastagem de capim Tobiatã (Panicum maximum cv. Tobiatã) sob pastejo rotacionado. Scientia Agricola, v.56, p.349-355, 1999.

VICENTE-CHANDLER, J.; SILVA, S.; FIGARELLA, J. Effect of nitrogen fertilization and frequency of cutting on the yield and composition of napier grass in Puerto Rico. Journal of Agriculture of the University of Puerto Rico, v.43, p.215-227, 1959.

Received August 09, 2004

Accepted July 22, 2005 